\title{
Drying Kinetics of Noni Seeds
}

\author{
Wellytton Darci Quequeto ${ }^{1}$, Osvaldo Resende ${ }^{1}$, Patrícia Cardoso Silva ${ }^{1}$, Fábio Adriano Santos e Silva ${ }^{1}$ \\ \& Lígia Campos de Moura Silva ${ }^{1}$ \\ ${ }^{1}$ Instituto Federal de Educação, Ciência e Tecnologia Goiano, Campus Rio Verde, Goiás, Brazil \\ Correspondence: Wellytton Darci Quequeto, Instituto Federal de Educação, Ciência e Tecnologia Goiano, \\ Campus Rio Verde, Goiás, Brazil. E-mail: wellytton_quequeto@hotmail.com
}

Received: January 16, 2019

doi:10.5539/jas.v11n5p250
Accepted: February 26, $2019 \quad$ Online Published: April 15, 2019

URL: https://doi.org/10.5539/jas.v11n5p250

\begin{abstract}
Noni seeds have been used for years as an important medicinal source, with wide use in the pharmaceutical and food industry. Drying is a fundamental process in the post-harvest stages, where it enables the safe storage of the product. Therefore, the present study aimed to fit different mathematical models to experimental data of drying kinetics of noni seeds, determine the effective diffusion coefficient and obtain the activation energy for the process during drying under different conditions of air temperature. The experiment used noni seeds with initial moisture content of 0.46 (decimal, d.b.) and dehydrated up to equilibrium moisture content. Drying was conducted under different controlled conditions of temperature, $40 ; 50 ; 60 ; 70$ and $80{ }^{\circ} \mathrm{C}$ and relative humidity, $24.4 ; 16.0 ; 9.9 ; 5.7$ and $3.3 \%$, respectively. Eleven mathematical models were fitted to the experimental data. The parameters to evaluate the fitting of the mathematical models were mean relative error $(\mathrm{P})$, mean estimated error (SE), coefficient of determination $\left(\mathrm{R}^{2}\right)$, Chi-square test $\left(\chi^{2}\right)$, Akaike Information Criterion (AIC) and Schwarz's Bayesian Information Criterion (BIC). Considering the fitting criteria, the model Two Terms was selected to describe the drying kinetics of noni seeds. Effective diffusion coefficient ranged from 8.70 to $23.71 \times$ $10^{-10} \mathrm{~m}^{2} \mathrm{~s}^{-1}$ and its relationship with drying temperature can be described by the Arrhenius equation. The activation energy for noni seeds drying was $24.20 \mathrm{~kJ} \mathrm{~mol}^{-1}$ for the studied temperature range.
\end{abstract}

Keywords: mathematical modeling, post-harvest, Morinda citrifolia L., effective diffusivity, activation energy

\section{Introduction}

Noni (Morinda citrifolia L.) is native to southeast Asia and Australia. Commercial plantations can be found in Tahiti, Hawaii and other countries of Polynesia, where most juices commercialized worldwide are produced (Silva et al., 2012).

Noni has been traditionally used for more than 2,000 years by Polynesia and such use is attributed to the effects related to antibacterial, antioxidant, antiviral, antifungal, antitumor, analgesic, anti-inflammatory, hypotensive and immunostimulant activity (Wang et al., 2002; Costa, Oliveira, Silva, Mancini-Filho, \& Lima, 2013; Lemos, Queiroz, \& Figueirêdo, 2015). Since there are no selected cultivars, commercial exploitation of noni is carried out using plants grown from seeds.

Drying consists in the removal of excess water contained in the seed by evaporation, which is usually obtained by hot-air forced convection. It can also be defined, according to Goneli, Nasu, Gancedo, Araújo and Sarath (2014), as a process which involves the simultaneous transfer of energy in the form of heat and mass between the product and the drying air, being one of the main steps of post-harvest.

Mathematical modeling is used to represent the drying kinetics of various products and involves conditions such as air temperature, relative humidity, air speed and characteristics of the product. Resende, Rodrigues, Siqueira, and Arcanjo (2010) report that these studies can be applied to drying processes and systems, dimensioning, optimization and evaluation of viability of the execution on commercial scale.

Several mathematical models have been successfully used by various researchers in agricultural products, such as annatto flour (Santos, Queiroz, Figueirêdo, \& Oliveira, 2013); rice grains (Corrêa, Oliveira, Oliveira, Botelho, \& Goneli, 2016); peanut fruits (Araujo, Goneli, Corrêa, Hartmann Filho \& Martins, 2017); sunflower grains (Smaniotto, Resende, Sousa, Oliveira, \& Campos 2017); common bean grains (Quequeto, Siqueira, Ferranti, Schoeninger, \& Leite, 2017); soybean grains (Botelho, Hoscher, Hauth, \& Botelho, 2018); potato (Lisboa et al., 2018) and blackberry leaves (Martins et al., 2018). 
To assess the fitting of the mathematical models to the drying data of plant products, several criteria can be used, such as the magnitudes of the mean relative error and mean estimated error, coefficient of determination, residual distribution and Chi-square test. However, some of these parameters have limitations, thus requiring the adoption of complementary criteria in the selection of the model to emphasize and endorse the decision-making. Thus, the Akaike Information Criterion (AIC) and Schwarz's Bayesian Information Criterion (BIC) consist in evaluating the models based on the parsimony principle, since the number of parameters in the models is variable (Gomes, Resende, Sousa, Oliveira, \& Araújo Neto, 2018; Ferreira Junior, Resende, Oliveira, \& Costa, 2018).

Given the above, the present study aimed to fit different mathematical models to the experimental data of drying kinetics of noni seeds, determine the effective diffusion coefficient and obtain the activation energy for the process during drying under different air temperature conditions.

\section{Material and Methods}

\subsection{Conduction of the Research}

The study was carried out at the Laboratory of Post-Harvest of Plant Products of the Federal Institute of Education, Science and Technology of Goiás, Campus of Rio Verde, located in the municipality of Rio Verde, GO, Brazil.

\subsection{Drying Kinetics}

Noni (Morinda citrifolia L.) seeds with initial moisture content of 0.46 (decimal, d.b.) were used. The moisture contents of the product were determined by the gravimetric method in an oven at $105 \pm 1{ }^{\circ} \mathrm{C}$, for 24 hours, in two repetitions (Brasil, 2009). Drying was conducted under different controlled conditions of temperature, 40; 50; 60; 70 and $80{ }^{\circ} \mathrm{C}$ and relative humidity, $24.4 ; 16.0 ; 9.9 ; 5.7$ and $3.3 \%$, respectively. Temperature and relative humidity of the ambient air were monitored by means of a data logger.

The seeds were dried on unperforated trays containing $0.15 \mathrm{~kg}$ of product in a completely randomized design, in four repetitions. During the drying process, the trays with samples were periodically weighed on a scale with resolution of $0.01 \mathrm{~g}$ until the product reached its equilibrium moisture content, i.e., constant mass.

Moisture content ratios of noni seeds during the drying, under the different air conditions, were determined using Equation 1 (Smaniotto et al., 2017):

$$
R X=\frac{X-X_{e}}{X_{i}-X_{e}}
$$

where, RX: moisture content ratio, dimensionless; X: moisture content of the product (decimal, d.b.); $\mathrm{X}_{\mathrm{e}}$ : equilibrium moisture content (decimal, d.b.); $\mathrm{X}_{\mathrm{i}}$ : initial moisture content (decimal, d.b.).

\subsection{Mathematical Modeling}

Mathematical models traditionally used to describe the thin-layer drying kinetics of agricultural products were fitted to the experimental data of drying, as described in Table 1.

Table 1. Mathematical models used to predict the thin-layer drying of agricultural products

\begin{tabular}{lll}
\hline Model designation & Models \\
\hline Page & $\mathrm{RX}=\exp \left(-\mathrm{kt}^{\mathrm{n}}\right)$ \\
Midilli & $\mathrm{RX}=\mathrm{a} \cdot \exp \left(-\mathrm{kt}^{\mathrm{n}}\right)+\mathrm{bt}$ & $(2)$ \\
Newton & $\mathrm{RX}=\exp (-\mathrm{kt})$ & \\
Thompson & $\mathrm{RX}=\exp \frac{\mathrm{a}-\left(\mathrm{a}^{2}+4 \mathrm{bt} \mathrm{t}^{0.5}\right.}{2 \mathrm{~b}}$ \\
Henderson and Pabis & $\mathrm{RX}=\mathrm{a} \cdot \exp (-\mathrm{kt})$ \\
Two Terms & $\mathrm{RX}=\mathrm{a} \cdot \exp \left(-\mathrm{k}_{0} \mathrm{t}\right)+\mathrm{b} \cdot \exp \left(-\mathrm{k}_{1} \mathrm{t}\right)$ & $(5)$ \\
Verma & $\mathrm{RX}=-\mathrm{a} \cdot \exp (-\mathrm{kt})+(1-\mathrm{a}) \cdot \exp \left(-\mathrm{k}_{1} \mathrm{t}\right)$ \\
Logarithmic & $\mathrm{RX}=\mathrm{a} \cdot \exp (-\mathrm{kt})+\mathrm{c}$ \\
Wang and Singh & $\mathrm{RX}=1+\mathrm{at}+\mathrm{bt} \mathrm{t}^{2}$ \\
Two-term Exponential & $\mathrm{RX}=\mathrm{a} \cdot \exp (-\mathrm{kt})+(1-\mathrm{a}) \cdot \exp (-\mathrm{kat})$ \\
Valcam & $\mathrm{RX}=\mathrm{a}+\mathrm{bt}+\mathrm{ct} \mathrm{ct}^{1.5} \mathrm{dt} \mathrm{t}^{2}$
\end{tabular}

Note. $\mathrm{t}$ : Drying time, $\mathrm{h} ; \mathrm{k}, \mathrm{k}_{0}, \mathrm{k}_{1}$ : Drying parameters $\mathrm{h}^{-1}$; and $\mathrm{a}, \mathrm{b}, \mathrm{c}, \mathrm{d}, \mathrm{n}$ : Coefficients of the models. 
The mathematical models were fitted to the experimental data of drying by nonlinear regression analysis, through the Gauss-Newton method, using a statistical program. The degree of fit for each drying temperature was determined considering the significance of the coefficients of regression by t-test, at 0.05 significance level, the magnitude of the coefficient of determination $\left(\mathrm{R}^{2}\right)$, mean relative error $(\mathrm{P})$, mean estimated error (SE) and the Chi-square test $\left(\chi^{2}\right)$ at 0.05 significance level, according to Equations 13,14 and 15.

$$
\begin{gathered}
\mathrm{P}=\frac{100}{\mathrm{n}} \sum_{\mathrm{i}=1}^{\mathrm{n}}\left(\frac{|\mathrm{Y}-\widehat{\mathrm{Y}}|}{\mathrm{Y}}\right) \\
\mathrm{SE}=\sqrt{\frac{\sum_{\mathrm{i}=1}^{\mathrm{n} \chi^{2}}}{\mathrm{GLR}}} \\
\chi^{2}=\sum_{\mathrm{i}=0}^{\mathrm{n}} \frac{(\mathrm{Y}-\widehat{\mathrm{Y}})^{2}}{\mathrm{GLR}}
\end{gathered}
$$

Where, Y: value observed experimentally; $\hat{Y}$ : value estimated by the model; n: number of experimental observations; and DF: degrees of freedom of the model.

In order to select a single model to describe with satisfaction the drying process of noni seeds under different air condition, the models which obtained the best fits were subjected to Akaike Information Criterion (AIC) and Schwarz's Information Criterion (BIC). According Wolfinger (1993), lower values of AIC and BIC indicate better fit of the model, and BIC is the strictest criterion. Gomes et al. (2018) state these criteria can be additionally included in the selection of drying models. These information criteria were determined by Eqs. 16 and 17.

$$
\begin{gathered}
\mathrm{AIC}=-2 \log \mathrm{L}+2 \mathrm{p} \\
\mathrm{BIC}=-2 \log \mathrm{L}+\mathrm{p} \ln (\mathrm{N}-\mathrm{r})
\end{gathered}
$$

Where, L: maximum likelihood; $\mathrm{p}$ : number of parameters of the model; $\mathrm{N}$ : total number of observations; and $\mathrm{r}$ : rank of the matrix $\mathrm{X}$ (incidence matrix for fixed effects).

\subsection{Effective Diffusion Coefficient}

The effective diffusion coefficient for the drying conditions was calculated by fitting the model, based on the liquid diffusion theory, to the observed data. This equation is the analytical solution for the second Fick's law, considering a cylindrical shape with six-term approximation (value established when diffusion coefficient variation is lower than $0.1 \times 10^{-13} \mathrm{~m}^{2} \mathrm{~s}^{-1}$ ), disregarding the volumetric shrinking of the seeds, according to Brooker, Bakker-Arkema, and Hall, (1992), using the following expression:

$$
\mathrm{RX}=\frac{\mathrm{X}-\mathrm{X}_{\mathrm{e}}}{\mathrm{X}_{\mathrm{i}}-\mathrm{X}_{\mathrm{e}}}=\sum_{\mathrm{n}=1}^{\alpha} \frac{4}{\lambda_{\mathrm{n}}^{2}} \cdot \exp \left(-\frac{\lambda_{\mathrm{n}}^{2} \cdot \mathrm{D} \cdot \mathrm{t}}{\mathrm{r}}\right)
$$

Where, t: drying time; D: liquid diffusion coefficient, $\mathrm{m}^{2} \mathrm{~s}^{-1}$; r: equivalent radius $(0.0051 \mathrm{~m})$; n: number of terms; and $\lambda_{\mathrm{n}}$ : roots of the zero-order Bessel's equation.

The volume $\left(\mathrm{V}_{\mathrm{s}}, \mathrm{mm}^{3}\right)$ of each seed was obtained by measuring the three orthogonal axes (length, width and thickness) in thirty seeds before drying, using a digital caliper, according to the expression proposed by Mohsenin (1986):

$$
\mathrm{V}_{\mathrm{s}}=\frac{\pi(\mathrm{abc})}{6}
$$

Where, a: seed longest axis; b: seed middle axis; c: seed shortest axis.

Equivalent sphere radius (r, mm) was determined using Equation 20:

$$
\mathrm{r}=\sqrt[3]{\frac{3 \mathrm{~V}_{\mathrm{s}}}{4 \pi}}
$$

The influence of temperature on the effective diffusion coefficient was evaluated using the Arrhenius equation, described as follows:

$$
\mathrm{D}_{\text {ef }}=\mathrm{D}_{0} \cdot \exp \left(\frac{\mathrm{E}_{\mathrm{a}}}{\mathrm{RT}_{\mathrm{a}}}\right)
$$

Where: $\mathrm{D}_{0}$ : pre-exponential factor; $\mathrm{R}$ : universal gas constant, $8.314 \mathrm{~kJ} \mathrm{kmol}^{-1} \mathrm{~K}^{-1}$; Ta: temperature, $\mathrm{K}$; and $\mathrm{E}_{\mathrm{a}}$ : activation energy, $\mathrm{kJ} \mathrm{mol}^{-1}$.

The coefficients of the Arrhenius equation were linearized by applying the following logarithm:

$$
\operatorname{LnD}=\operatorname{LnD}_{0}-\frac{E_{a}}{R} \cdot \frac{1}{T_{a}}
$$




\section{Results and Discussion}

Table 2 shows the magnitudes of the mean relative error (P, \%), mean estimated error (SE, decimal), coefficient of determination $\left(\mathrm{R}^{2}, \%\right)$ and Chi-square test $\left(\chi^{2}\right.$, decimal) for the eleven models fitted, during the drying of noni seeds under the different air conditions.

Table 2. Statistical parameters obtained for the eleven models fitted to describe the thin-layer drying of noni seeds under different temperature conditions

\begin{tabular}{|c|c|c|c|c|c|c|c|c|c|c|}
\hline \multirow{2}{*}{ Models } & \multicolumn{2}{|c|}{$40^{\circ} \mathrm{C}$} & \multicolumn{2}{|c|}{$50^{\circ} \mathrm{C}$} & \multicolumn{2}{|c|}{$60^{\circ} \mathrm{C}$} & \multicolumn{2}{|c|}{$70^{\circ} \mathrm{C}$} & \multicolumn{2}{|c|}{$80^{\circ} \mathrm{C}$} \\
\hline & $\mathrm{P}$ & $\mathrm{SE}$ & $\mathrm{P}$ & SE & $\mathrm{P}$ & SE & $\mathrm{P}$ & SE & $\mathrm{P}$ & SE \\
\hline (2) & 9.6453 & 0.0145 & 5.1538 & 0.0115 & 3.1754 & 0.0057 & 13.9373 & 0.0119 & 13.5536 & 0.0218 \\
\hline (3) & 7.4228 & 0.0102 & 6.7811 & 0.0109 & 3.8226 & 0.0055 & 4.5705 & 0.0057 & 2.3903 & 0.0059 \\
\hline (4) & 30.0947 & 0.0427 & 15.2642 & 0.0258 & 4.1205 & 0.0058 & 18.0614 & 0.0133 & 17.1940 & 0.0234 \\
\hline (5) & 4.1139 & 0.0087 & 6.0862 & 0.0076 & 2.2928 & 0.0055 & 9.2948 & 0.0093 & 10.3460 & 0.0181 \\
\hline (6) & 24.4868 & 0.0349 & 12.4547 & 0.0230 & 3.9765 & 0.0059 & 17.7621 & 0.0136 & 17.0296 & 0.0242 \\
\hline (7) & 2.9883 & 0.0072 & 4.8345 & 0.0065 & 3.1383 & 0.0054 & 2.3494 & 0.0050 & 2.4380 & 0.0056 \\
\hline (8) & 2.6576 & 0.0084 & 15.2596 & 0.0270 & 3.1236 & 0.0056 & 18.0614 & 0.0141 & 2.9132 & 0.0099 \\
\hline (9) & 12.9446 & 0.0170 & 82.4013 & 0.1375 & 3.4236 & 0.0057 & 2.4264 & 0.0059 & 3.4721 & 0.0104 \\
\hline (10) & 84.9693 & 0.1290 & 57.7342 & 0.0831 & 51.7075 & 0.0589 & 83.4109 & 0.0885 & 31.3259 & 0.0550 \\
\hline (11) & 17.7895 & 0.0226 & 15.2641 & 0.0264 & 2.3093 & 0.0056 & 18.0613 & 0.0137 & 17.1940 & 0.0242 \\
\hline (12) & 8.5382 & 0.0127 & 5.2472 & 0.0080 & 3.6587 & 0.0079 & 5.9356 & 0.0088 & 3.5228 & 0.0127 \\
\hline \multirow{2}{*}{ Models } & \multicolumn{2}{|c|}{$40^{\circ} \mathrm{C}$} & \multicolumn{2}{|c|}{$50^{\circ} \mathrm{C}$} & \multicolumn{2}{|c|}{$60^{\circ} \mathrm{C}$} & \multicolumn{2}{|c|}{$70^{\circ} \mathrm{C}$} & \multicolumn{2}{|c|}{$80^{\circ} \mathrm{C}$} \\
\hline & $\mathrm{R}^{2}$ & $\chi^{2}$ & $\mathrm{R}^{2}$ & $\chi^{2}$ & $\mathrm{R}^{2}$ & $\chi^{2}$ & $\mathrm{R}^{2}$ & $\chi^{2}$ & $\mathrm{R}^{2}$ & $\chi^{2}$ \\
\hline (2) & 99.7012 & 0.1027 & 99.8248 & 0.0560 & 99.9617 & 0.0349 & 99.8273 & 0.1540 & 99.4476 & 0.1536 \\
\hline (3) & 99.8605 & 0.0844 & 99.8584 & 0.0807 & 99.9680 & 0.0467 & 99.9646 & 0.0565 & 99.9687 & 0.0313 \\
\hline (4) & 97.3209 & 0.3103 & 99.0867 & 0.1590 & 99.9584 & 0.0432 & 99.7729 & 0.1896 & 99.3205 & 0.1827 \\
\hline (5) & 99.8915 & 0.0438 & 99.9243 & 0.0662 & 99.9661 & 0.0252 & 99.8962 & 0.1027 & 99.6205 & 0.1173 \\
\hline (6) & 98.2707 & 0.2607 & 99.3063 & 0.1354 & 99.9590 & 0.0437 & 99.7751 & 0.1963 & 99.3226 & 0.1930 \\
\hline (7) & 99.9305 & 0.0340 & 99.9496 & 0.0576 & 99.9689 & 0.0384 & 99.9726 & 0.0290 & 99.9206 & 0.0319 \\
\hline (8) & 99.9029 & 0.0292 & 99.0867 & 0.1734 & 99.9686 & 0.0362 & 99.7729 & 0.0790 & 99.8945 & 0.0354 \\
\hline (9) & 99.6036 & 0.1424 & 76.2406 & 0.9364 & 99.9686 & 0.0396 & 99.9724 & 0.0283 & 99.8835 & 0.0422 \\
\hline (10) & 76.3111 & 0.9045 & 90.9385 & 0.6275 & 95.9445 & 0.5688 & 90.4938 & 0.9219 & 96.4892 & 0.3550 \\
\hline (11) & 99.2704 & 0.1894 & 99.0867 & 0.1659 & 99.9667 & 0.0254 & 99.7729 & 0.1996 & 99.3205 & 0.1949 \\
\hline (12) & 99.7853 & 0.0972 & 99.9239 & 0.0625 & 99.9348 & 0.0447 & 99.9152 & 0.0733 & 99.8386 & 0.0461 \\
\hline
\end{tabular}

In relation to the mean relative error (P), it can be observed that only the models Midilli (3), Two Terms (7) and Valcam (12) had values lower than $10 \%$ for all drying temperatures studied. According to Mohapatra and Rao (2005), this parameter can be used to recommend or not a model. Mean relative error values reflect the deviation of the observed values relative to the curve estimated by the model (Kashaninejad, Mortazavi, Safekordi \& Tabil, 2007). Thus, in this case, the deviation can be considered as acceptable for the models evaluated.

According to Draper and Smith (1998), the mean estimated error (SE) indicates the capacity of a model to accurately describe a certain physical process, and the lower its magnitude, the better the fitting quality of the model relative to the experimental data. Thus, the model Two terms stood out among the others, for showing the lowest values under all different conditions of the drying air (Table 2), hence demonstrating a good fit.

Based on the coefficient of determination $\left(\mathrm{R}^{2}\right)$, only the models Newton, Henderson and Pabis, Logarithmic and Wang and Singh were below 99\%. According to Kashaninejad et al. (2007), models with coefficients of determination above $98 \%$ can satisfactorily represent the drying phenomenon. Nevertheless, Mohapatra and Rao (2005) report that the coefficient of determination as single criterion of evaluation to select drying models is not a good parameter to represent the drying phenomenon.

Table 2 also shows that all models had low values in the Chi-square test $\left(\chi^{2}\right)$, and the higher the value of $\chi^{2}$, the higher also the discrepancy between experimental values and the expected trend (Molina Filho, Pedro, Telis-Romero, \& Barbosa, 2006). 
Schwarz's Bayesian Information Criterion (BIC) and Akaike Information Criterion (AIC) (Table 3) were also used as complementary parameters to select the best model among the ones that stood out regarding the previously calculated statistical parameters (Midilli, Two Terms and Valcam).

Table 3. Values of Akaike Information Criterion (AIC) and Schwarz's Bayesian Information Criterion (BIC) for the models that obtained the best fit to the drying data of noni seeds under different temperature conditions

\begin{tabular}{|c|c|c|c|c|c|c|c|c|c|c|}
\hline \multirow{2}{*}{ Models } & \multicolumn{2}{|c|}{$40^{\circ} \mathrm{C}$} & \multicolumn{2}{|c|}{$50^{\circ} \mathrm{C}$} & \multicolumn{2}{|c|}{$60^{\circ} \mathrm{C}$} & \multicolumn{2}{|c|}{$70^{\circ} \mathrm{C}$} & \multicolumn{2}{|c|}{$80^{\circ} \mathrm{C}$} \\
\hline & $\mathrm{AIC}$ & $\mathrm{BIC}$ & AIC & BIC & AIC & $\mathrm{BIC}$ & AIC & BIC & $\overline{\mathrm{AIC}}$ & BIC \\
\hline (3) & -221.152 & -213.235 & -111.665 & -105.570 & -160.789 & -155.334 & -151.771 & -146.548 & -106.955 & -102.789 \\
\hline (7) & -249.461 & -241.544 & -118.390 & -112.295 & -161.414 & -155.958 & -157.166 & -151.943 & -122.888 & -118.722 \\
\hline (12) & -205.023 & -197.105 & -96.263 & -90.168 & -145.157 & -139.702 & -133.433 & -128.210 & -94.884 & -90.718 \\
\hline
\end{tabular}

Considering the lowest values of AIC and BIC (Table 3), the model Two terms (7) showed the best fit to the experimental data. Thus, this model was selected to represent the drying kinetics of noni seeds. Gomes et al. (2018) and Ferreira Junior et al. (2018) also obtained satisfactory results using AIC and BIC to select mathematical models in studies in the field of post-harvest.

Figure 1 shows the thin-layer drying curves $\left(40,50,60,70\right.$ and $\left.80^{\circ} \mathrm{C}\right)$ of noni seeds, represented by the model Two terms. The correspondence between experimental and estimated values and the satisfactory fit of the model Two terms under all studied conditions can be observed in the graph. Several researchers have recommended this model to predict the drying process of different agricultural products: jatropha seeds (Siqueira, Resende, \& Chaves, 2012); annatto flour (Santos et al., 2013); common bean grains (Quequeto et al., 2017); niger seeds (Silva, Siqueira, Quinzani, Martins, \& Goneli, 2017); cowpea seeds (Camicia, Christ, Coelho, \& Camicia, 2015); baru fruit mesocarp (Oliveira, Oliveira, Resende, \& Silva, 2018); yacon potato (Lisboa et al., 2018) and 'Cabacinha' pepper seeds (Silva, Vale Junior, Silva, Souza, \& Soares, 2018).

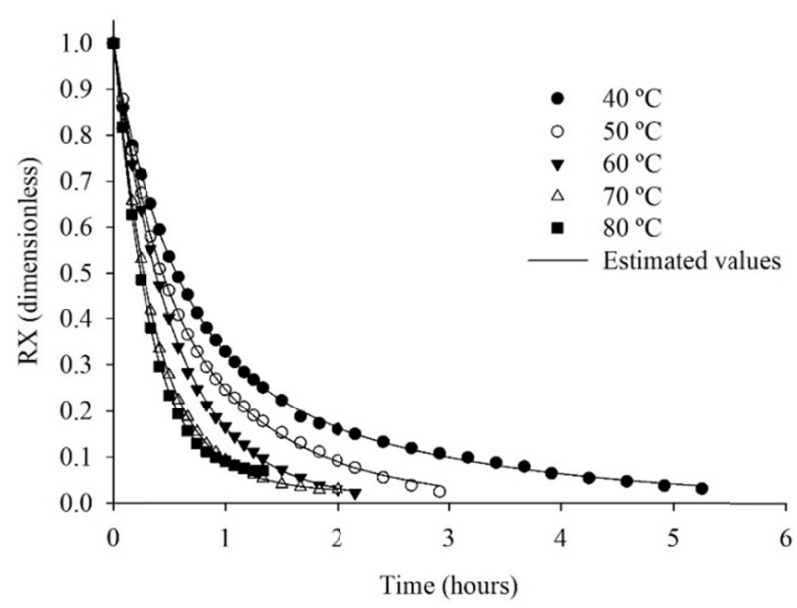

Figure 1. Moisture content ratios obtained experimentally and estimated by the model Two terms for the thin-layer drying of noni seeds under different temperature conditions

Table 4 shows the parameters of the model Two terms fitted to the experimental data during the thin-layer drying of noni seeds, for different air temperature conditions. It can be noted that there was no specific behavior for the values of the parameters as the drying air temperature increased. 
Table 4. Estimated values of the parameters of the model two terms for different air temperature conditions in the drying of noni seeds

\begin{tabular}{lllll}
\hline \multirow{2}{*}{ Temperatures $\left({ }^{\circ} \mathrm{C}\right)$} & \multicolumn{3}{c}{ Parameters } \\
\cline { 2 - 5 } & $\mathrm{a}$ & $\mathrm{b}$ & $\mathrm{k}_{0}$ & $\mathrm{k}_{1}$ \\
\hline $40^{\circ} \mathrm{C}$ & $0.6350^{* *}$ & $0.3461^{* *}$ & $1.8171^{* *}$ & $0.4270^{* *}$ \\
$50{ }^{\circ} \mathrm{C}$ & $0.5781^{* *}$ & $0.4307^{* *}$ & $0.9405^{* *}$ & $2.9208^{* *}$ \\
$60{ }^{\circ} \mathrm{C}$ & $0.0187^{\mathrm{ns}}$ & $0.9828^{* *}$ & $0.4080^{\mathrm{ns}}$ & $1.8683^{* *}$ \\
$70^{\circ} \mathrm{C}$ & $0.0291^{*}$ & $0.9802^{* *}$ & $0.0886^{\mathrm{ns}}$ & $2.7158^{* *}$ \\
$80^{\circ} \mathrm{C}$ & $0.0085^{\mathrm{ns}}$ & $1.0070^{* *}$ & $-1.3979^{*}$ & $2.9959^{* *}$ \\
\hline
\end{tabular}

Note. ${ }^{* *}$ Signicant at $0.05 ;{ }^{*}$ Signicant at $0.10 ;{ }^{\text {ns }}$ Not significant by t-test.

Figure 2 presents the mean values of the effective diffusion coefficient (A) within the temperature range from 40 and $80{ }^{\circ} \mathrm{C}$ and the values of $\mathrm{Ln} \mathrm{D}$ as a function of the inverse of absolute temperature $\left(1 / \mathrm{K}^{-1}\right)(\mathrm{B})$ determined for the drying of noni seeds. During the drying, the effective diffusion coefficients showed magnitudes from 8.70 to $23.71 \times 10^{-10} \mathrm{~m}^{2} \mathrm{~s}^{-1}$ for the temperature range from 40 to $80{ }^{\circ} \mathrm{C}$. According to Madamba, Driscoli, and Buckle (1996), the effective diffusion coefficient for the drying of agricultural products varies from $10^{-9}$ to $10^{-11} \mathrm{~m}^{2} \mathrm{~s}^{-1}$. Therefore, the values calculated for noni seeds are within the reported range.
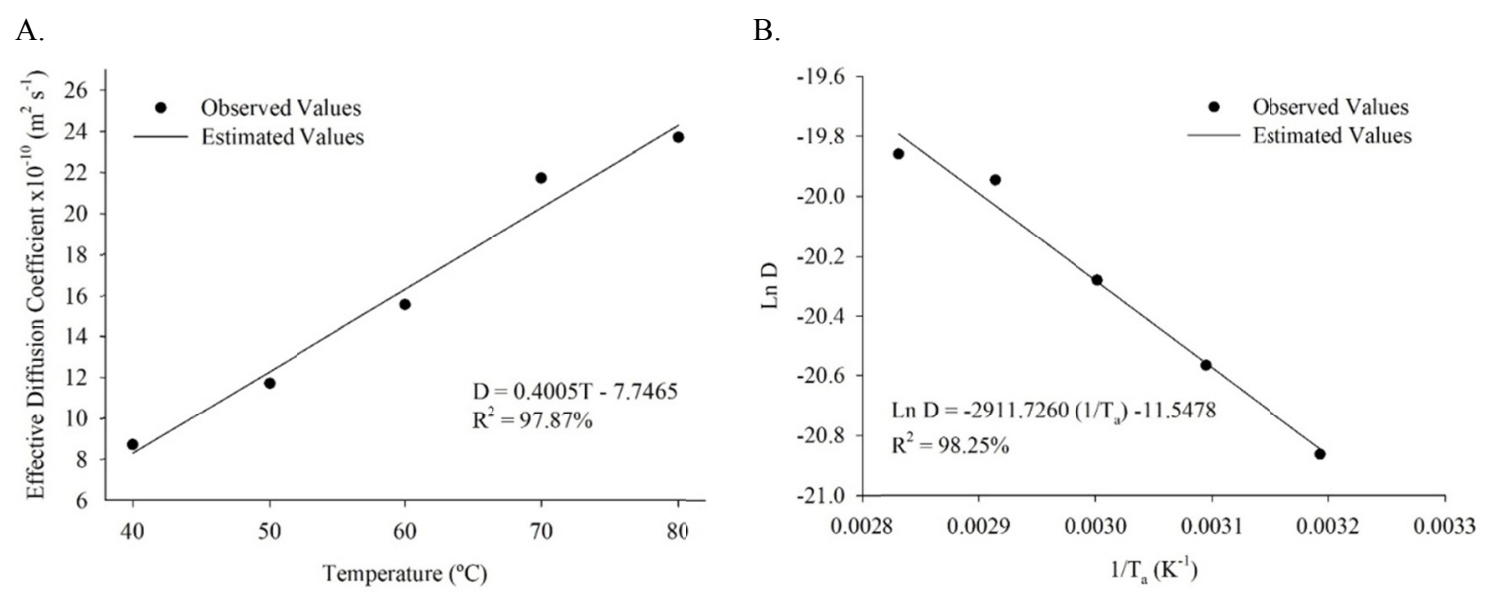

Figure 2. Values of effective diffusion coefficient (A) and Arrhenius representation for the effective diffusion coefficient $(B)$ of the noni seeds as a function of drying air temperature

It can be observed that the effective diffusion coefficients of noni seeds increased linearly with increasing drying air temperature. This relationship can be described by the Arrhenius representation (Figure 2B), agreeing with the results reported by Smaniotto et al. (2017) and Botelho et al. (2018). According to Araujo et al. (2017), the increase of temperature promotes reduction in water viscosity, a measure of resistance, so it leads to alterations in water diffusion through the product's capillaries, favoring the displacement of this fluid from the interior to the edges.

The activation energy for the drying of noni seeds was $24.20 \mathrm{~kJ} \mathrm{~mol}^{-1}$ within the studied range of temperatures. According to Corrêa, Martinazzo, Goneli, and Botelho (2007), activation energy indicates the ease with which water molecules overcome the energy barrier during their movement inside the product. Thus, the lower the activation energy, the higher the water diffusivity in the product.

Equation 23 presents the coefficients of the fitted equation for the effective diffusion coefficient of noni seeds, calculated using Equation 22.

$$
\mathrm{D}=9.6553 \times 10^{-6} \cdot \exp \left(-\frac{24207.8738}{\mathrm{RT}_{\mathrm{a}}}\right)
$$

The activation energy found in the present study was lower than that obtained by Camicia et al. (2015) for cowpea, $35.04 \mathrm{~kJ} \mathrm{~mol}^{-1}$, and higher than the value reported by Oliveira, Resende, Smaniotto, Campos, and Chaves (2012) for corn, $19.09 \mathrm{~kJ} \mathrm{~mol}^{-1}$. According to Martins, Lage, Goneli, Hartmann Filho, and Lopes (2015), 
the biological and physical characteristics of the different agricultural products can influence the variations of the values activation energy.

\section{Conclusions}

The model Two terms showed the best fit to the data and was selected to describe the drying kinetics of noni seeds.

The effective diffusion coefficient tends to increase with elevating temperature, showing values from 8.6968 to $23.7089 \times 10^{-10} \mathrm{~m}^{2} \mathrm{~s}^{-1}$.

The activation energy was equal to $24.20 \mathrm{~kJ} \mathrm{~mol}^{-1}$, obtained through the Arrhenius equation, which establishes the dependence of the diffusivity in relation to the temperature.

\section{Acknowledgements}

The authors extend thanks to IF Goiano, CAPES, FAPEG, FINEP and CNPq for their financial support, which was indispensable to the execution of this study.

\section{References}

Araujo, W. D., Goneli, A. L. D., Corrêa, P. C., Hartmann Filho, C. P., \& Martins, E. A. S. (2017). Modelagem matemática da secagem dos frutos de amendoim em camada delgada. Revista Ciência Agronômica, 48(3), 448-457. https://doi.org/10.5935/1806-6690.20170052

Botelho, F. M., Hoscher, R. H., Hauth, M. R., \& Botelho, S. D. C. C. (2018). Cinética de secagem de grãos de soja: influência varietal. Revista Engenharia na Agricultura, 26(6), 13-25. https://doi.org/10.13083/reveng. v26i1.807

Brasil. (2009). Regras para análise de sementes (p. 395). Ministério da Agricultura, Pecuária e Abastecimento. Secretaria de Defesa Agropecuária. Brasília, DF: Mapa/ACS.

Brooker, D. B., Bakker-Arkema, F. W., \& Hall, C. W. (1992). Drying and Storage of Grains and Oilseeds (p. 450). Westport: The AVI Publishing Company.

Camicia, R. G. da M., Christ, D., Coelho, S. R. M., \& Camicia, R. F. da M. (2015). Modelagem do processo de secagem de sementes de feijão-caupi. Revista Caatinga, 28(3), 206-214. https://doi.org/10.1590/1983-2125 $2015 v 28 n 323 r c$

Corrêa, P. C., Resende, O., Martinazzo A. P., Goneli, A. L. D., \& Botelho, F. M. (2007). Modelagem matemática para a descrição do processo de secagem do feijão (Phaseolus vulgaris L.) em camadas delgadas. Engenharia Agrícola, 27(2), 501-510. https://doi.org/10.1590/S0100-69162007000300020

Corrêa, P. C., Oliveira, G. H. H. de, Oliveira, A. P. L. R. de, Botelho, F. M., \& Goneli, A. L. D. (2016). Thermodynamic properties of drying process and water absorption of rice grains. CyTA-Journal of Food, 15(2), 204-210. https://doi.org/10.1080/19476337. 2016.1238012

Costa, A. B., Oliveira, A. D., Silva, A. M. O., Mancini-Filho, J., \& Lima, A. (2013). Atividade antioxidante da polpa, casca e sementes do noni (Morinda citrifolia Linn). Revista Brasileira de Fruticultura, 35(2), 345-354. https://doi.org/10.1590/S0100-29452013000200003

Draper, N. R., \& Smith, H. (1998). Applied regression analysis (3rd ed., p. 712). New York: John Wiley \& Sons. https://doi.org/10.1002/9781118625590

Ferreira Junior, W. N., Resende, O., Oliveira, D. E. C. de., \& Costa, L. M. (2018). Isotherms and isosteric heat desorption of Hymenaea stigonocarpa Mart. seeds. Journal of Agricultural Science, 10(10), 504-512. https://doi.org/10.5539/jas.v10n10p504

Gomes, F. P., Resende, O., Sousa, E. P., Oliveira, D. E. C. de, \& Araújo Neto, F. R. D. (2018). Drying kinetics of crushed mass of 'jambu': Effective diffusivity and activation energy. Revista Brasileira de Engenharia Agrícola e Ambiental, 22(7), 499-505. https://doi.org/10.1590/1807-1929/agriambi.v22n7p499-505

Goneli, A. L. D., Nasu, A. K., Gancedo, R., Araújo, W. D., \& Sarath, K. L. L. (2014). Cinética de secagem de folhas de erva baleeira (Cordia verbenacea DC.). Revista Brasileira de Plantas Medicinais, 16(2), 434-443. https://doi.org/10.1590/1983-084X/13_041

Kashaninejad, M., Mortazavi, A., Safekordi, A., \& Tabil, L. G. (2007). Thin-layer drying characteristics and modeling of pistachio nuts. Journal of Food Engineering, 78(1), 98-108. https://doi.org/10.1016/j.jfoodeng. 2005.09.007 
Lemos, D. M., Figueiredo, R. M., Queiroz, A. J., \& da Silva, S. F. (2015). Caracterização físico-química de sementes de noni. Revista GEINTEC-Gestão, Inovação e Tecnologias, 5(3), 2308-2315. https://doi.org/10. 7198/S2237-0722201500030008

Lisboa, C. G. de, Gomes, J. P., Figueirêdo, R. M. de, Queiroz, A. J. D. M., Diógenes, A. D. M., \& Melo, J. (2018). Effective diffusivity in yacon potato cylinders during drying. Revista Brasileira de Engenharia Agricola e Ambiental, 22(8), 564-569. https://doi.org/10.1590/1807-1929/agriambi.v22n8p564-569

Madamba, P. S., Driscoli, R. H., \& Buckle, K. A. (1996). Thin layer drying characteristics of garlic slices. Journal of Food Engineering, 29(1), 75-97. https://doi.org/10.1016/ 0260-8774(95)00062-3

Martins, E. A. S., Lage, E. Z., Goneli, A. L. D., Hartmann Filho, C. P., \& Lopes, J. G. (2015). Cinética de secagem de folhas de timbó (Serjania marginata Casar). Revista Brasileira de Engenharia Agrícola e Ambiental, 19(3), 238-244. https://doi.org/10.1 590/1807-1929/agriambi.v19n3p238-244

Martins, E. A. S., Goneli, A. L. D., Goncalves, A. A., Hartmann Filho, C. P., Siqueira, V. C., \& Oba, G. C. (2018) Drying kinetics of blackberry leaves. Revista Brasileira de Engenharia Agrícola e Ambiental, 22(8), 570-576. https://doi.org/10.1590/1807-1929/agriambi.v22n8p570-576

Mohapatra, D., \& Rao, P. S. (2005). A thin layer drying model of parboiled wheat. Journal of Food Engineering, 66(4), 513-518. https://doi.org/10.1016/j.jfoodeng.2004.04.023

Molina Filho, L., Pedro, M. A. M., Telis-Romero, J., \& arbosa, S. H. R. (2006). Influência da temperatura e da concentração do cloreto de sódio $(\mathrm{NaCl})$ nas isotermas de sorção da carne de tambaqui (Colossoma macroparum). Ciência e Tecnologia de Alimentos, 26(2), 453-458. https://doi.org/10.1590/S0101-20612006 000200032

Mohsenin, N. N. (1986). Physical properties of plant and animal materials (p. 841). New York: Gordon and Breach Publishers.

Oliveira, P. M. D., Oliveira, D. E. C. de, Resende, O., \& Silva, D. V. (2018). Study of the drying of mesocarp of baru (Dipteryx alata Vogel) fruits. Revista Brasileira de Engenharia Agrícola e Ambiental, 22(12), 872-877. https://doi.org/10.1590/1807-1929/agriambi.v22n12p872-877

Oliveira, D. E. C., Resende, O., Smaniotto, T. A. de S., Campos, R. C., \& Chaves, T. H. (2012). Cinética de secagem dos grãos de milho. Revista Brasileira de Milho e Sorgo, 11(2), 190-201. https://doi.org/10.18512/ 1980-6477/rbms.v11n2p190-201

Quequeto, W. D., Siqueira, V. C., Ferranti, L. F., Schoeninger, V., \& Leite, R. A. (2017). Cinética de secagem dos grãos de feijão cultivar IPR Tangará. Revista Energia na Agricultura, 32(4), 408-415. https://doi.org/ 10.17224/EnergAgric.2017v32n4p408-415

Resende, O., Rodrigues, S., Siqueira, V. C., \& Arcanjo, R. V. (2010). Cinética da secagem de clones de café (Coffea canephora Pierre) em terreiro de chão batido. Acta Amazônica, 40(2), 247-256. https://doi.org/ $10.1590 / \mathrm{S} 0044-59672010000200002$

Santos, D. D. C., Queiroz, A. J. D. M., Figueirêdo, R. M. de, \& Oliveira, E. N. de. (2013). Cinética de secagem de farinha de grãos residuais de urucum. Revista Brasileira de Engenharia Agrícola e Ambiental, 17(2), 223-231. https://doi.org/10.1590/S1415-4366201300020 0014

Silva, L. R. da, Medeiros, P. V. Q. de, Leite, G. A., Silva, K. J. P., Mendonça, V., \& Silva, G. G. da. (2012). Caracterização do fruto de Morinda citrifolia L. (noni). Revista Cubana de Plantas Medicinales, 17(1), 93-100.

Silva, F. P. da, Siqueira, V. C., Quinzani, G. A., Martins, E. A. S., \& Goneli, A. L. D. (2017). Drying kinetics of niger seeds. Engenharia Agrícola, 37(4), 727-738. https://doi.org/10.1590/1809-4430-eng.agric.v37n4p727 $-738 / 2017$

Silva, H. W. D., Vale Junior, L. S., Silva, C. F., Souza, R. D. C., \& Soares, R. S. (2018). Drying kinetics and physiological quality of 'Cabacinha'pepper seeds during storage. Revista Brasileira de Engenharia Agricola e Ambiental, 22(4), 292-297. https://doi.org/10.1590/1807-1929/agriambi.v22n4p292-297

Siqueira, V. C., Resende, O., \& Chaves, T. H. (2012). Drying kinetics of Jatropha seeds. Revista Ceres, 59(2), 171-177. https://doi.org/10.1590/S0034-737X2012000200004

Smaniotto, T. A. D. S., Resende, O., Sousa, K. A. D., Oliveira, D. E. C. de, \& Campos, R. C. (2017). Drying kinetics of sunflower grains. Revista Brasileira de Engenharia Agrícola e Ambiental, 21(3), 203-208. https://doi.org/10.1590/1807-1929/agriambi.v21n3p203-208 
Wang, M. Y., West, B., Jensen, C. J., Nowicki, D., Su, C., Palu, A. K., \& Anderson, G. (2002). Morinda citrifolia (Noni): A literature review and recent advances in Noni research. Acta Pharmacologica Sínica, 23(12), 1127-1141.

Wolfinger, R. D. (1993). Covariance structure selection in general mixed models. Communications in Statistics, 22(4), 1079-1106. https://doi.org/10.1080/03610919308813143

\section{Copyrights}

Copyright for this article is retained by the author(s), with first publication rights granted to the journal.

This is an open-access article distributed under the terms and conditions of the Creative Commons Attribution license (http://creativecommons.org/licenses/by/4.0/). 